few of these cases would appear to die of cancer, for the simple reason that they do not attain the cancer age.

I have mentioned elsewhere that not all cases go on to a full perforation or prolapse. Some are left with a corneal scar or scars and one eye may appear to be completely spared. A retinoscopy in such an eye will, however, often betray irregular corneal 'swirls' without any actual opacity, which suggests that some minimal, subclinical damage has been suffered by the corneal lamellae, producing no more than a modicum of irregular astigmatism.

What is the exact value and purpose of connective tissue? As it is perhaps the most important repository of the materials of repair and nutriment, the highway for arteries, nerves and tissue fluids, one would imagine that any permanent damage to its components might at an earlier or a later stage lead to changes in the epithelia and endothelia which it underlies, supports and nourishes.

My thanks are due to previous house surgeons; to Sister Lord, my out-patient sister, for invaluable help; to my wife, Dr S. Girardin, for help in compiling this paper, and to Dr Steyn, Superintendent of the Frere Hospital, East London, South Africa, for permission to photograph and publish records of patients.

\title{
REFERENCES
}

Blumenthal, C. J. (1950). S. Afr. med. F. 24, 191.

Blumenthal, C. J. (1954). S. Afr. med. $\mathcal{F} . \mathbf{2 8}, 967$.

\section{EXPLANATION OF PLATE}

$a$. A very rare example of an unusually large spontaneous iris prolapse in an African male 9 years old. On section this prolapse was covered by a continuous layer of unbroken corneal epithelium.

b. A very rare example of triple spontaneous iris prolapse in an African girl i 6 years old. A recent organizing prolapse at Io o'clock and two healed old prolapses at 3 o'clock and 6 o'clock can be seen. Note triangular pupil.

\section{Protein and myopia}

\section{By P. A. Gardiner (Research Fellow in Ophthalmology), Guy's Hospital, London, S.E.I}

Acquired myopia is a disease which usually begins between the ages of 7 and II, but virtually always before physical growth stops. Deterioration in vision occurs in most children once myopia has begun, again until growth stops. The rate of deterioration is strongly associated with the rate of physical growth, those who grow fast and irregularly whether in weight or height deteriorate faster during these periods than those who grow slowly and more regularly. The situation in the eye, put simply, is that in the higher degrees of myopia the eyeball is always longer antero-posteriorly than a normal eye. In the lower degrees there is no association with the size of the eye. The condition is often optically due to increased curvature of the cornea relative 


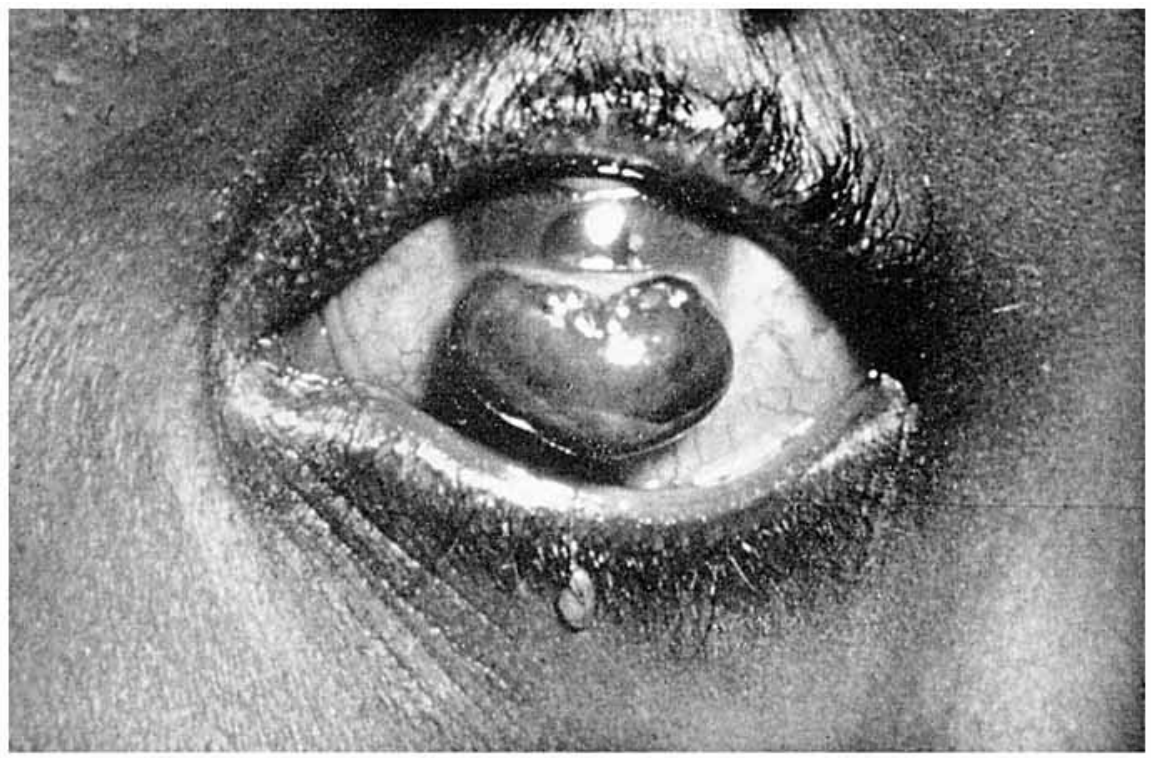

(a)

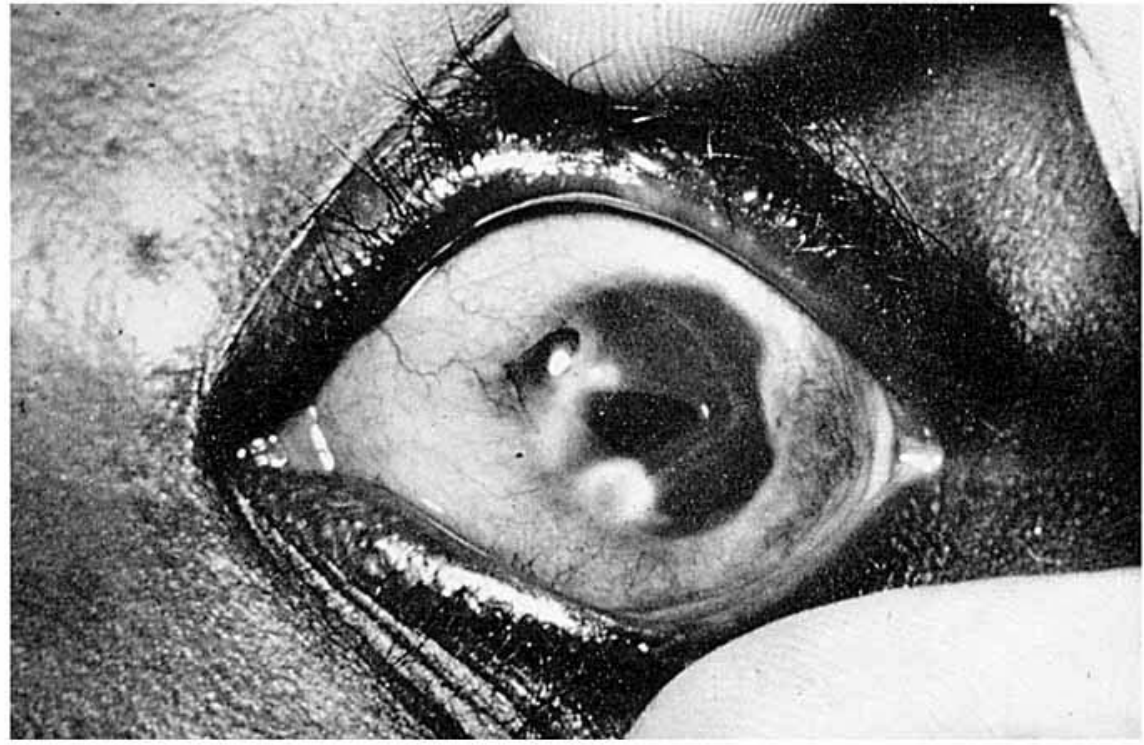

(b)

Proceedings of The Nutrition Society, Vol. I9, No. I

(Facing p. 96) 
to the antero-posterior length of the eye and theoretically to increased lens size, though some doubt is cast on this possibility by authorities such as Sorsby, Benjamin, Davey, Sheridan \& Tanner (I957). In my series of cases all grades of myopia are included and no attempt has been made to segregate those eyes that are large from those that are of normal size. This may account for some discrepancies and I think that keratometry readings should be used in research into myopia before conclusions can be firmly made whether myopia is a simple condition-optically speaking - or a complex of conditions. Finally in this summary of the simpler facts about myopia it is important to realize that retinal and vitreous degenerations in early middle age leading to detachments of the retina and other visual disasters are very much more common among myopes than in any other refractive condition. No reliable figures of the incidence of the disease are obtainable, but preliminary figures from a survey $I$ have conducted indicate that in 1400 schoolchildren of 14 years old in London I I \% of boys and $14 \%$ of girls were myopic. In the rural districts of Cambridge $5 \%$ of boys and $8 \%$ of girls were myopic. These findings indicate the size of the problem. Out of this $10-15 \%$ of the population come the majority of those becoming blind between the ages of 35 and 50 .

Since myopia in its developing stages is so closely associated with growth, I am not the only one who has considered that nutrition might play a part in governing its appearance and the degree of myopia that may eventually be attained. Duke-Elder (1949) mentions calcium deficiency, vitamin D deficiency and vitamin A deficiency as having been seriously considered by reputable workers as being prime factors in the aetiology of myopia. This is not the time to enter into a discussion on the possible causes of the condition but Duke-Elder also mentions twenty-nine other causes apart from the nutritional ones I have referred to. Many of these are contradictory, and I would therefore like to make it clear that in the work I am about to describe all the cases were of established myopia and I have no direct evidence to offer about its cause.

Analysis of the dietary intakes of myopic children by the ordinary clinical method of question and answer enabled me to show that a discrepancy occurs between the diets of myopes and others. Not only do myopic children refuse animal protein sources more often than normally sighted children, but those deteriorating most rapidly refuse most frequently (Gardiner, 1956).

In my initial investigations $I$ found that deteriorating myopes consumed relative to their rate of growth less of all foods than other children, the discrepancy being most marked in animal protein. Treatment of a group of myopic children with a high intake of animal protein showed a beneficial result compared with controls (Gardiner, 1958).

I was not altogether satisfied with these results because close analysis showed that girls under 12 years of age were comparatively resistant to treatment and, as Table I shows, a very high intake of animal protein was not as beneficial as a slightly lower one.

I have therefore recently completed a further analysis of these diets. This group of children were all having a diet high in animal protein. Consecutive 6-month 19 (1) 8 
Table 1. Animal-protein intake and change in refraction in children

$\begin{array}{ccc}\begin{array}{c}\text { Calories derived from } \\ \text { animal protein } \\ \text { (percentage of total) }\end{array} & \begin{array}{c}\text { No. of } \\ \text { children }\end{array} & \begin{array}{c}\text { Mean annual change } \\ \text { in refraction (dioptres) }\end{array} \\ >11.0 & 12 & -0.33 \\ 10.0-11.0 & 18 & -0.14 \\ 9.0-9.9 & 22 & -0.15 \\ 7.0-8.9 & 39 & -0.25 \\ <7.0 & 21 & -0.37 \\ \chi^{2} \text { (omitting those over } 11 \% \text { ) } & =4.12 ; P<0.05\end{array}$

periods were considered. During the second 6 months the variation in the behaviour of their myopia was compared with what had occurred in the first 6 months. It was found that those who did better in the second 6 months than in the first consumed very much the same diet as previously, except for vegetable protein, than those whose eyes did worse (Table 2).

Table 2. Change in vegetable-protein consumption with rate of visual deterioration in children

\begin{tabular}{|c|c|c|c|c|c|c|}
\hline \multirow{2}{*}{$\begin{array}{l}\text { Vegetable-protein } \\
\text { intake }\end{array}$} & \multicolumn{3}{|c|}{$\begin{array}{l}\text { No, with less } \\
\text { deterioration }\end{array}$} & \multicolumn{3}{|c|}{$\begin{array}{l}\text { No. with more } \\
\text { deterioration }\end{array}$} \\
\hline & Girls & Boys & Total & Girls & Boys & Total \\
\hline Decrease & 10 & 7 & 17 & 19 & 12 & 31 \\
\hline No change & 12 & 14 & 26 & 9 & 8 & 17 \\
\hline Increase & I I & I I & 22 & II & 5 & 16 \\
\hline
\end{tabular}

This finding led me to survey all the treated children, and again significant differences were found in the consumption of vegetable protein. It was definitely more significant amongst boys than girls and once more the girls between 7 and 12 were anomalous (Table 3 ).

The myopic changes occurring in association with a high ratio of intake of animal to vegetable protein do not show any increase until this ratio rises above 3 . At this point there is a sharp increase in the amount of change shown in all the groups analysed (Table 4 ).

Table 3. Intake of vegetable protein and increase in myopia in children

\begin{tabular}{|c|c|c|c|c|}
\hline \multirow{3}{*}{$\begin{array}{c}\text { Vegetable-protein } \\
\text { intake } \\
\text { (g/lb body-weight) }\end{array}$} & \multicolumn{4}{|c|}{ Mean increase in myopia (dioptres) in 6 months } \\
\hline & \multicolumn{2}{|c|}{ Boys } & \multicolumn{2}{|c|}{ Girls } \\
\hline & $7-12$ years & $13-16$ years & $7-12$ years & I3-16 years \\
\hline 0 & 0.37 & 0.20 & 0.25 & 0.28 \\
\hline $0.1-0.2$ & 0.30 & 0.18 & 0.26 & 0.18 \\
\hline $0.3-0.4$ & 0.21 & $0 \cdot 16$ & 0.27 & 0.09 \\
\hline 0.4 & 0.09 & 0.1 & 0.24 & \\
\hline
\end{tabular}


Table 4. Ratio of intake of animal to intake of vegetable protein and increase in myopia (dioptres) in children in 6 months

\begin{tabular}{|c|c|c|c|c|c|}
\hline \multirow{3}{*}{$\begin{array}{c}\text { Ratio, } \\
\text { animal : vegetable } \\
\text { protein }\end{array}$} & \multicolumn{2}{|c|}{ Boys } & \multicolumn{2}{|c|}{ Girls } & \multirow[b]{2}{*}{ AII } \\
\hline & $7^{-12} 2$ years & I3-16 years & 7-12 years & I3-16 years & \\
\hline & 0.29 & $0.1 \mathrm{I}$ & 0.19 & 0.03 & 0.16 \\
\hline 2 & 0.14 & 0.13 & 0.24 & 0.19 & 0.16 \\
\hline 3 & 0.14 & O. I 5 & $0 \cdot 18$ & 0.07 & 0.14 \\
\hline 4 & 0.39 & 0.70 & $0 \cdot 39$ & 0.23 & 0.38 \\
\hline$>4$ & 0.33 & 0.24 & 0.26 & 0.14 & 0.24 \\
\hline
\end{tabular}

In this series of cases the total protein intake did not show as close a correlation with the changes in myopia as the ratio of animal protein to vegetable protein.

\section{Discussion}

Looked at from an ophthalmological point of view, the main interest of these results lies in the bearing they may have on the perennial argument as between the genetic or environmental theories of the myopic process. Whatever may be the theoretical or actual explanation of these results, they strongly indicate that myopia is capable of being modified by dietary means -if only to a limited extent.

Within the general context of the growth and nutrition of children, the position appears to be that in protein-starved communities such as the Bantu, myopia does not occur-a fact kindly confirmed for me by Dr I. Macdonald on one of the visits to South Africa when he temporarily turned ophthalmologist.

The same result was obtained with rabbits when we tried to modify the adult refraction by dietary means during the growing ages of the animal. Within a limited range of protein deficiency, there was a correlation between its amount and the adult refraction (Gardiner \& Macdonald, 1958), but if the protein deficiency in terms of the protein intake of a control group exceeded $300 \mathrm{~g}$ over the total period, no effect was to be found on the eyes.

I therefore feel that one can say that myopia is a disease of relatively well-fed communities. Vision appears to deteriorate most in those children who grow irregularly and precociously. This deterioration can be beneficially modified by giving a diet relatively high in animal protein. Amongst these children those whose eyes deteriorated least were those who also took a relatively high proportion of vegetable protein.

Before concluding I would like to draw attention to the difference between the findings with girls before the age of 12 and those with older girls and with boys. The younger group of girls consistently showed less significant response to treatment and less significant relation to protein intake. They also exhibited a greater rate of growth than boys and, in the untreated group studied, a greater natural rate of increase in myopia (unpublished observations). Close study of these children showed that the greatest rate of myopic increase in any group of children was in the year before menarche occurs in girls. 
This finding I think is very significant as showing that diet cannot be paramount in the control of this condition but only contributory. My own conception is that there may also be either a direct hormonal influence or possibly some indirect influence through, for example, water balance. There is evidence in young adults who do not normally exhibit changes in myopia that when these changes do occur they are very frequently synchronous with rapid weight increase. I have digressed somewhat from the subject of protein and its association with myopia, but although the connexion eludes me I feel that as protein has a well-known connexion with fluid balance there may well be some interrelationship between increase in myopia, changes in weight and the hormonal control of growth in which the protein intake and associated interrelationships might play a part.

In conclusion, I am most grateful to The Nutrition Society for its farsightedness in promoting a discussion on this subject.

\section{REFERENCES}

Duke-Elder, W. S. (I949). Textbook of Ophthalmology, Vol. 4. London: Henry Kimpton.

Gardiner, P. A. (1956). Brit. med. F. ii, 699.

Gardiner, P. A. (1958). Lancet, i, I 152.

Gardiner, P. A. \& Macdonald, I. (1958). Proc. Nutr. Soc. 17, xx.

Sorsby, A., Benjamin, B., Davey, J. B., Sheridan, M. \& Tanner, J. M. (1957). Spec. Rep. Ser. med. Res. Coun., Lond., no. 293.

\section{Vitamin $B_{12}$ and the eye}

\section{By J. M. Heaton, Department of Ophthalmology, University of Bristol*}

The main ocular conditions in which vitamin $\mathrm{B}_{12}$ has been suggested to play an important part are diabetic retinopathy and certain cases of optic neuritis.

\section{Diabetic retinopathy}

The position as regards vitamin $\mathrm{B}_{12}$ and diabetes is in a state of flux at present. That diabetics have an abnormality in vitamin $\mathrm{B}_{12}$ metabolism was first postulated by Becker, Lang \& Chow (1953). They observed that in diabetics without retinopathy urinary excretion of an injected dose of vitamin $B_{12}$ was subnormal whereas in those with retinopathy excretion was abnormally high. Support for this finding came from Stone \& Chow (1957), who studied urinary excretion of radioactive vitamin $\mathrm{B}_{12}$ given by mouth using the method of Schilling. Also Chow, Rosen \& Lang (I954) reported that patients with retinopathy have a significantly higher serum vitamin $B_{12}$ level than those without it.

Recently Halsted, Carroll \& Rubert (1959) found that diabetic patients with retinopathy and proven renal disease have a significantly higher serum-vitamin $B_{12}$ level than those with or without retinal lesions but no renal disease. As renal insufficiency has been shown to reduce urinary excretion of cobalt-labelled vitamin $B_{12}$,

\footnotetext{
* Present address: Institute of Ophthalmology (University of London), Judd Street, London, W.C. I.
} 